Z. klin. Chem. u. klin. Biochem.

10. Jg. 1972 , S. $220-225$

\title{
Useful Buffer and Gel Systems for Polyacrylamide Gel Electrophoresis
}

\author{
By H. R. Maurer and R. C. Allen \\ Max-Planck-Institut für Virusforschung, Tübingen, and Institut für gericktliche Medizin der 'Universität Heidelberg
}

(Eingegangen am 10. November 1971)

\begin{abstract}
Seven buffer and gel systems for polyacrylamide gel electrophoresis using discontinuous voltage and pH gradients (disc electrophoresis according to ORNSTENN-DAvis) and five systems using discontinuous voltage gradients at constant pH (according to AlLEN) have been compiled and characterized. Usefulness and applicability of the systems for clinical investigations are discussed and illustrated by several serum protein separations.
\end{abstract}

Sieben bewährte Puffer- und Gelsysteme für die Polyacrylamidgel-Elektrophorese mittels diskontinuierlicher Spannungs- und pHGradienten (Disk-Elektrophorese nach ORNSTErN-DavIs) und fünf Systeme für die Gel-Elektrophorese mittels diskontinuierlichem Spannungsgradienten bei konstantem pH-Wert (nach ALLEN) wurden zusammengestellt und charakterisiert. Die Brauchbarkeit der Systeme wurde diskutiert und an mehreren Beispielen von Serumprotein-Trennungen erläutert.

Although the high resolving power of polyacrylamide gel electrophoresis has proved valuable in clinical, biochemical and biological research at the molecular level $(1-3)$, the usefulness and applicability of this method has been relatively little recognized or utilized in practical clinical chemistry for routine diagnosis and therapy control. There may be two main reasons for this.

First, there are, in some cases, many possible interpretations of the complicated protein patterns obtained with polyacrylamide gel electrophoresis. At the moment, a satisfactory interpretation of all the complex patterns is not possible. An example of these difficulties in interpretation is the overlapping of $\alpha_{2}$-globulins with $\beta$ and $\gamma$-globulins of normal human serum. The $\gamma$-globulins represent a broad complex which may be difficult to evaluate, since it extends as a protein background for $\alpha_{2}$ - and $\beta$-globulins from the start to the $\alpha_{2}$-zone. Suitable reference systems, for the identification and characterization of the proteins under study may help to solve these method-inherent problems.

A second obstacle for the wide use of the method may be a technical one. Although there are various suitable apparatus systems commercially available, it appears that the techniques involved in the operation of most apparatus still require a certain degree of practical skill to obtain reproducible results. Moreover, as yet more correlative studies between laboratories are needed to provide satisfactory data on the standardization of sample preparation, separation and staining as well as on the standardization of gel formation. To this end, a further requirement is for buffer and gel systems which through adequate testing have been found to yield reproducible separations among different laboratories.

We have compiled several buffer and gel systems which have been successfully used in our and other laboratories. Although a sophisticated theory of multi- phasic buffer systems has been formulated and a computer program based on this theory developed (4), we trust that the buffer and gel systems recorded in our tables will yield satisfactory separations in many cases, since they have been practically examined many times and found to work efficiently. These systems will be described and their applicability discussed. Examples illustrating the type of separations obtainable with various buffer and gel formulations will be presented. Problems related to the standardization of polyacrylamide gel electrophoresis for use in clinical chemistry will be dealt with in a subsequent paper (5).

\section{Characterization of and Comments on the Gel and Buffer Systems for Polyacrylamide Gel Electro- phoresis}

Table 1 lists several gel and buffer systems based on the principles of the original disc electrophoresis as formulated by OrNStEIN and Davis $(6,7)$. This technique utilizes both a discontinuous voltage and $\mathrm{pH}$ gradient to create the conditions of the KOHLRAUSCH regulating function for zone sharpening of sample components. While a continuous system employs the same buffers for electrode reservoirs and supporting medium (gel), a discontinuous system is composed of two buffers with a slower moving (trailing) ion in the electrode buffer and a faster moving (leading) ion in the gel and sample buffer. During electrophoresis the trailing ion. displaces the position occupied by the leading ion, thereby sandwiching the sample components at the moving boundary. The principles of disc electrophoresis require $\mathrm{pH}$ differences between electrode, spacer and separation gel buffer to achieve the needed effective mobilities of the trailing ions. It is clear that the rather broad $\mathrm{pH}$ shifts during disc electrophoresis may, in some cases; give rise to concentration artefacts (irreversible protein interactions) and to the loss of bio- 


\section{Wåchst Ihrem Labor die Arbeit über den Ropof?}

Mit dem SILAB-System können Sie den gesamten Untersuchungsablauf praktisch voll automatisieren von der Untersuchungsanforderung über die Probenanalyse bis zur Ergebnisdarstellung.

Das SILAB-System ist nach dem Baukastenprinzip in drei Einzelsysteme gegliedert:

- Das SILAB-Identifikationssystem ordnet Untersuchungsgut und Meßdaten dem Patienten unverwechselbar zu.

oDas SILAB-Datenerfassungssystem sammelt, normiert und konzentriert die von den verschiedenen Laborgeräten anfallenden Daten.

- Das SILAB-Programmsystem, ein Software-Paket, bietet Programme für laufende Meßwertkontrolle, automatische Ergebnisberechnung und individuelle Ergebnisausgabe.

Und noch ein entscheidendes Argument für SILAB: Ob in Klinik oder Praxis Sie können mit unserem System medizinische Laboratorien jeder Größenordnung voll- oder teilautomatisieren.

Für weitere Informationen wenden Sie sich bitte an unsere nächstgelegene Geschäftsstelle oder an: SIEMENS AKTIENGËSELLSCHAFT Med Dv - 8520 Erlangen . Postfach 400
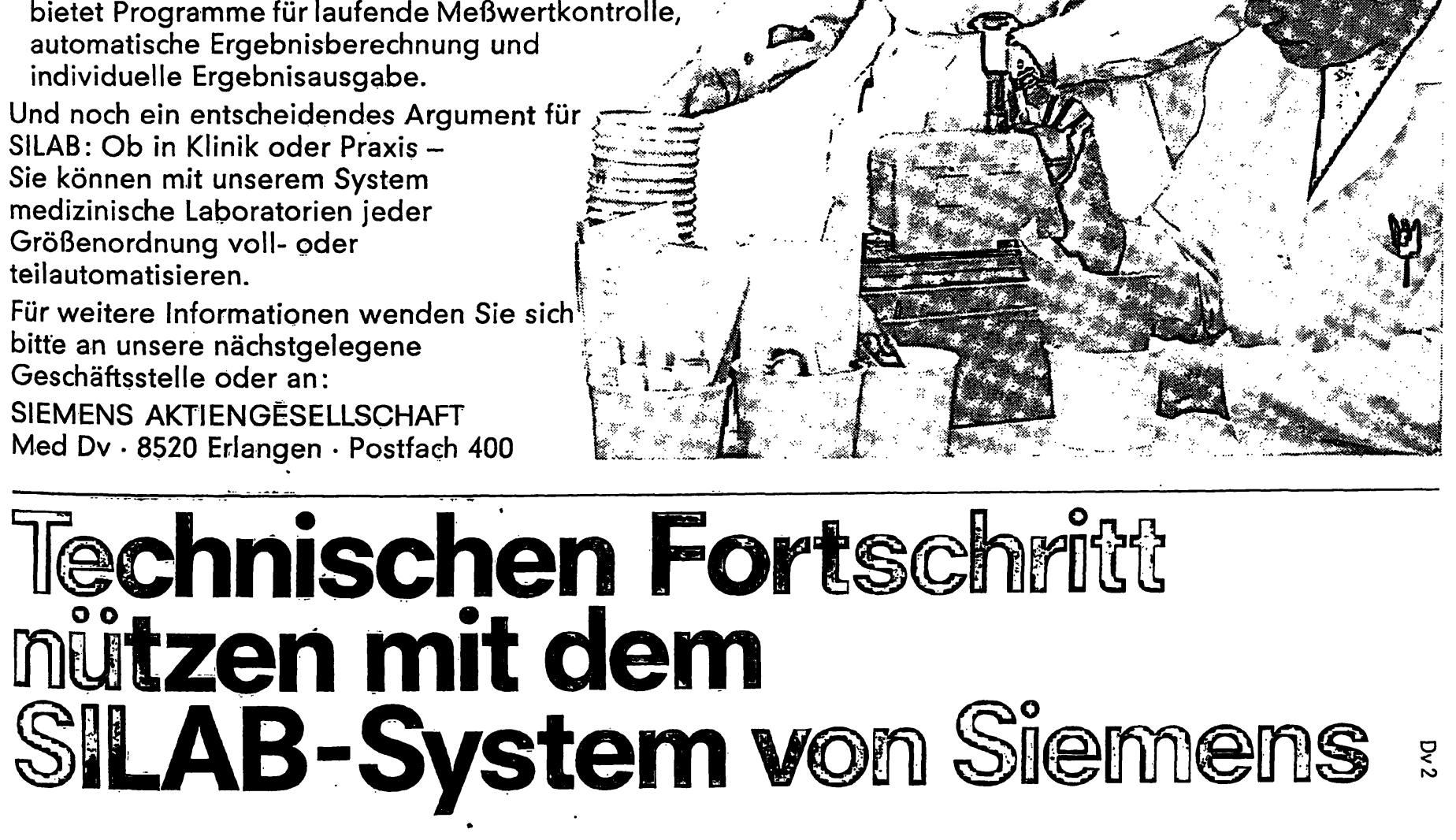


\section{Medizinischer}

\section{DOLMETSCHER in Bildern}

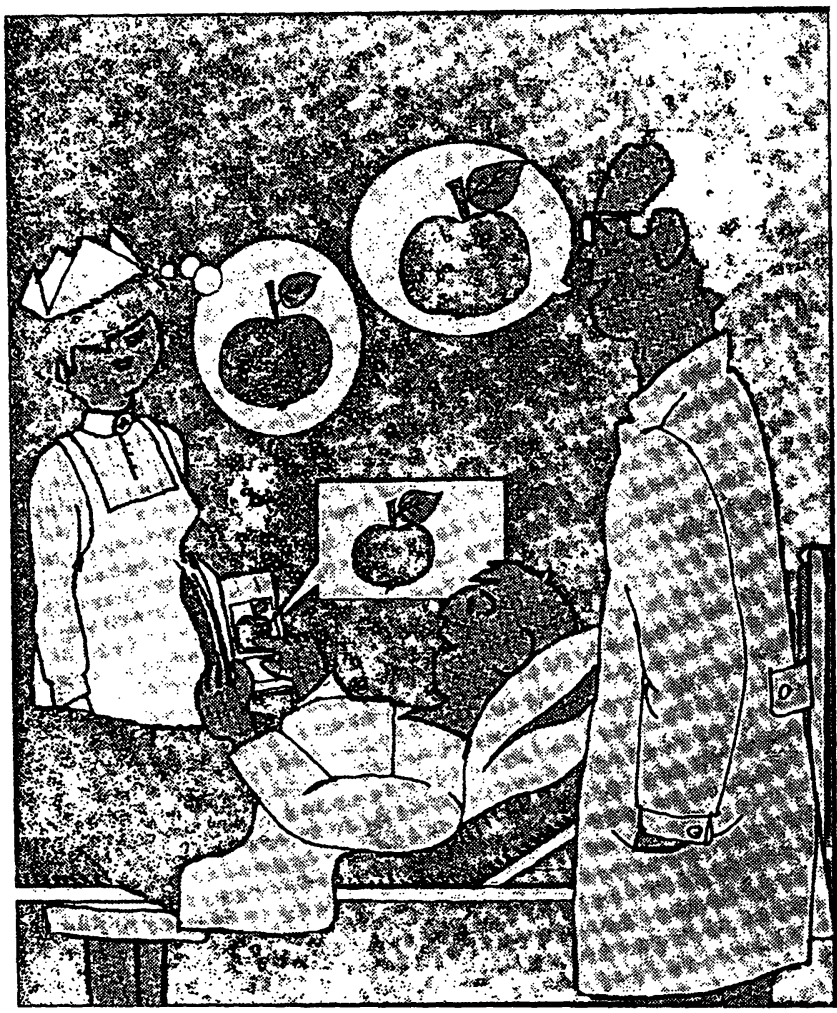

von Professor Dr. med.

Jack Adams-Ray

Verständigung leicht gemacht - im Ausland, mit Gastarbeitern und ausländischen Touristen

\section{über alle Probleme eines Kranken mit Arzt und Schwester}

durch anschauliche Symbole. Kurztexte deutsch, englisch, französisch, griechisch, italienisch, polnisch, russisch, serbo-kroatisch, spanisch, türkisch

Einzelstück DM 5.- (fPr)

ab 10 Stück DM 4.-, ab 100 DM 3.-

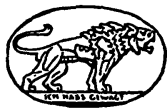

J.F. LEHMANNS VERLAG MÜNCHEN

\section{Ärger mit den schläuchen\}}

Wir bei Heidolph wissen dairum

und bietedthnet deshalicice Pumpespryano

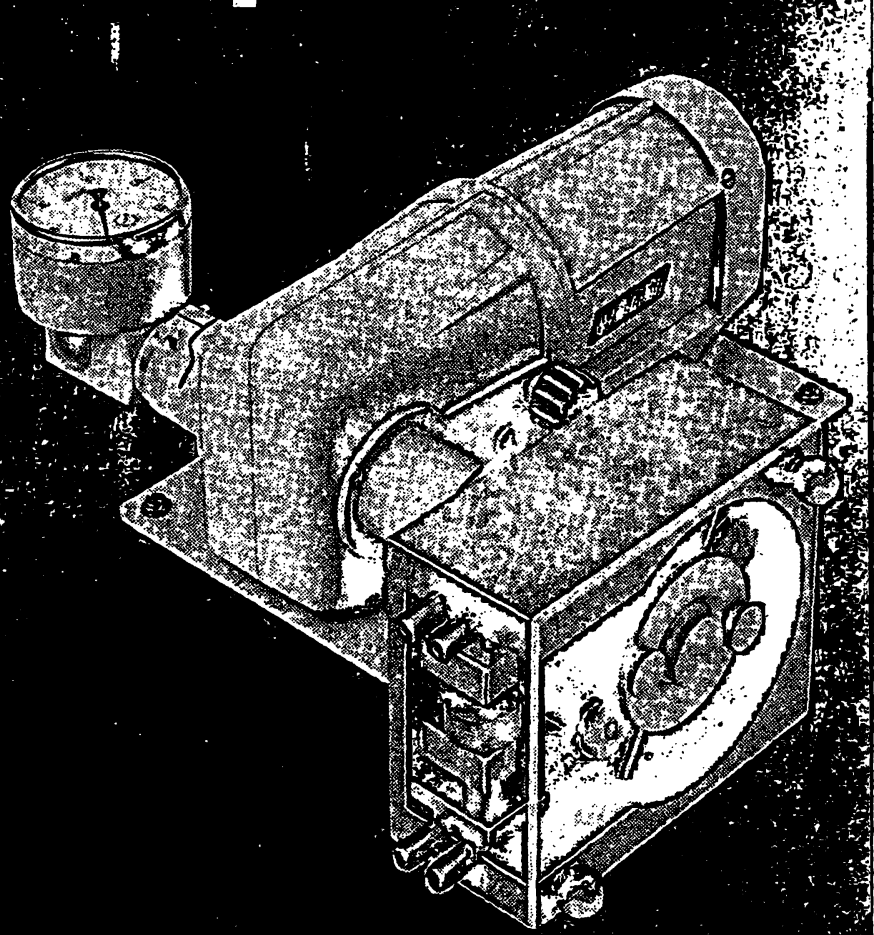

Nicht mehr starr der Abstand zwischen Anpreßflächen und Rollen, sondern anpassungs: fähig an Schläuche mit Wandstärken zwischén $0 ; 5$ und $2,5 \mathrm{~mm}$ und lichten Weiten zwischen, 2 und $8 \mathrm{~mm}$. Und das ohne Werkzeug!

Stufenlos regelbar die Drehzahl. Abzulesen: auf dem angebauten Drehzahlmesser.

Damit Sie dies alles als wesentliche Vorteile beurteilen können, senden wir Ihnen auf Anforderung gerne ausführliches Informationsmaterial.

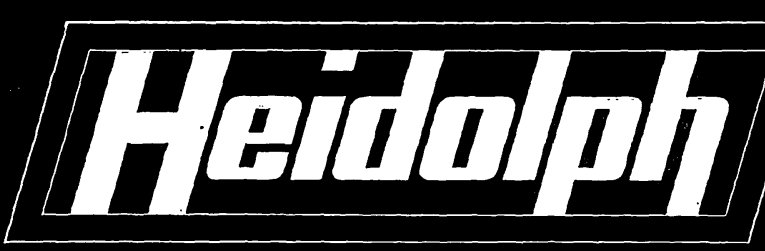

Heidolph-Elektro KG · D 8420 Kelheim/Germany Telefon (0 94 41) 7533 . Telex $065415 d$ 







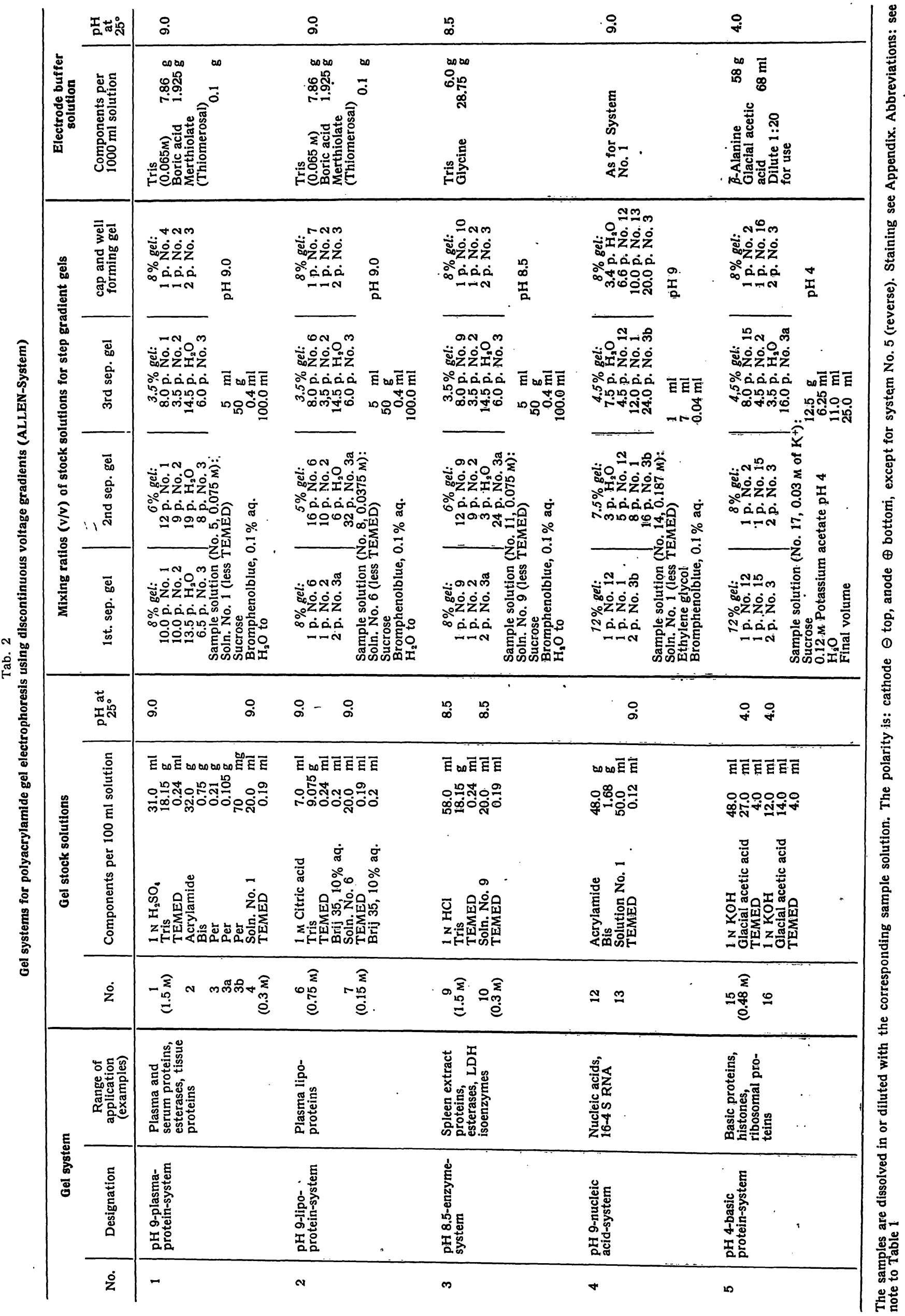


logical activity. Therefore, attention should always be given to $\mathrm{pH}$ influences to which the sample components are exposed in every disc electrophoretic run. For example, in the standard alkaline gel system No. 1 of Table 1, the sample components are dissolved in

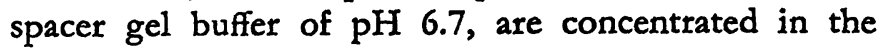
spacer gel at $\mathrm{pH} 8.3$ and are separated in the separation gel at $\mathrm{pH} 9.5$.

Moreover, the ion species used for the moving boundary may influence the activity of enzymes. E. g., the alkaline phosphatase of serum which shows several bands in polyacrylamide gel electrophoresis is inhibited by glycinate, the trailing ion of gel system No. 1 . Inactivation of enzymes may also be caused by photopolymerization of the sample gel or by interaction with other catalysts of gel polymerization. The pertinent aspects of polymerization artifacts are discussed elsewhere (1).

Gel system No. 1 is widely used for the separation of proteins (e. g. of serum) of molecular weights between $10^{4}$ and $10^{6}$ which are stable at the $\mathrm{pHs}$ indicated (7). System No. 2 (8) and No. 3 (9) are suited for proteins which are unstable above $\mathrm{pH} 8.5$ and 8.0 , respectively. System No. 4 (10) catches basic proteins which migrate retrograde (to cathode) in gel system No. 1 . The latter gel system normally separates anionic substances with free mobilities in the range of -0.6 to -7.5 units. However, proteins with intermediate mobilities $(-0.75$ to 1.0 ), such as the $S_{\alpha^{-}}, S_{\beta^{-}}$and $\gamma$-globulins, may be better resolved by gel system No. 5 (11). Gel systems No. 6 (12) and 7 (8) are suited for basic proteins, such as histones, proteohormones and ribosomal proteins. To create a steeper voltage gradient, resulting in improved resolution, glycine may be replaced by valine in the anionic (upper) electrode buffer of gel system No. 7. Valine has a similar buffering capacity to glycine, but a lower mobility at $\mathrm{pH} 4.0$ (13).

The gel and buffer systems of Table 2, developed by Allen (14-16), separate the sample components on the basis of discontinuous voltage gradients at a uniform $\mathrm{pH}$ throughout. Essentially, they combine two methods for sample concentration, $i$. e., the principle of conductivity shift described by HJERTÉN (17) and the moving boundary technique first described by PouLIK (18). A conductivity shift is readily generated by lowering the ionic strength of the sample buffer with respect to that of the separating medium. This concentrating method avoids possible harmful effects arising from $\mathrm{pH}$ discontinuities, but has a limited concentrating capacity. The moving boundary technique, operating under the conditions described by the KoHLRAUSCr regulating function, sharpens the zones of already separated components, thus improving resolution considerably. The technique also uses discontinuous buffers with leading and trailing ions, which, however, in contrast to the disc electrophoresis systems, have a uniform $\mathrm{pH}$ throughout the total system, since the mobility of the trailing ion is constant in this system.
Gel system No. 1 of Table 2, a sulfate-borate discontinuous buffer system, has proved valuable for the separation of many serum proteins, enzymes and tissue proteins which are stable at $\mathrm{pH} 9.0$. In order to utilize the potential of the molecular sieving effect of the gel, a step gradient gel is recommended: First a $8 \%$ gel (with respect to acrylamide), then a $6 \%$ and a $3.5 \%$ gel are polymerized on top of each other. For Gc type proteins a $12-8-6-3.5 \%$ step gradient gel is advised. Following sample application into the pockets of the well gel, an additional cap gel is cast on top of the samples to physically separate the samples from the trailing ions in the upper electrode reservoir. Thus, the moving boundary formed by the leading-trailing ions is maintained above the sample components during initial separation by charge and size in the first separating gel. The ionic strength of the cap gel is less than that of the separating gel to increase the velocity of the moving boundary. If the persulfate used as catalyst for the gel formation interferes with the enzyme or other activity of the biological material to be separated, the well and cap gel may be photopolymerized rather than chemically polymerized.

Addition of thioglycolate or mercaptoethanol ( $5 \mathrm{~mm}$ ) may help to reduce the oxygen-rich state of the gel due to persulfate decomposition $(19,20)$.

The citrate-borate system No. 2 is suited for serum proteins, particularly lipoproteins, which tend to aggregate. Citrate and borate are chelating agents which might prevent extensive aggregation due to ion interactions. Addition of a non-ionic detergent, such as Brij 35, supports the dissociation of clustering lipoproteins. The tris-glycine system No. 3 is recommended as a substitute for the borate systems, if this ion should complex with sugar and carbohydrate-containing components leading to bent protein zones (21). Gel system No. 4 is a modified gel system No. 1 for optimum separation of nucleic acids (4-16 S RNA). Finally, gel system No. 5 was developed on the basis of gel system No. 6 of Table 1 for the fractionation of basic proteins at $\mathrm{pH} 4$.

It should be added that reducing the ionic strength of the separating gels of systems No. 1 and 3 to one half has recently been found to give equal or better resolution, utilizing lower voltage and lower current densities with reduced Joule heating.

Figure 1 shows the type of pattern of human serum proteins obtainable with the standard ORNSTEIN-Davis system No. 1 (Tab. 1), a discontinuous glycine-chloride buffer system, while Figure 2 demonstrates human serum patterns produced with ALLEN system No. 1, a pH-continuous, sulfate-borate-discontinous buffer system using a $8-6-3.5 \%$ step concentration gradient. A comparison reveals that the latter system yields more and sharper bands, particularly in the preand postalbumin region. This difference is more pronounced, hence the resolution is improved, if the ionic strength of Allen's system is reduced to one half and the step gradient changed to include a $12 \%$ gel (Fig. 3 ). 


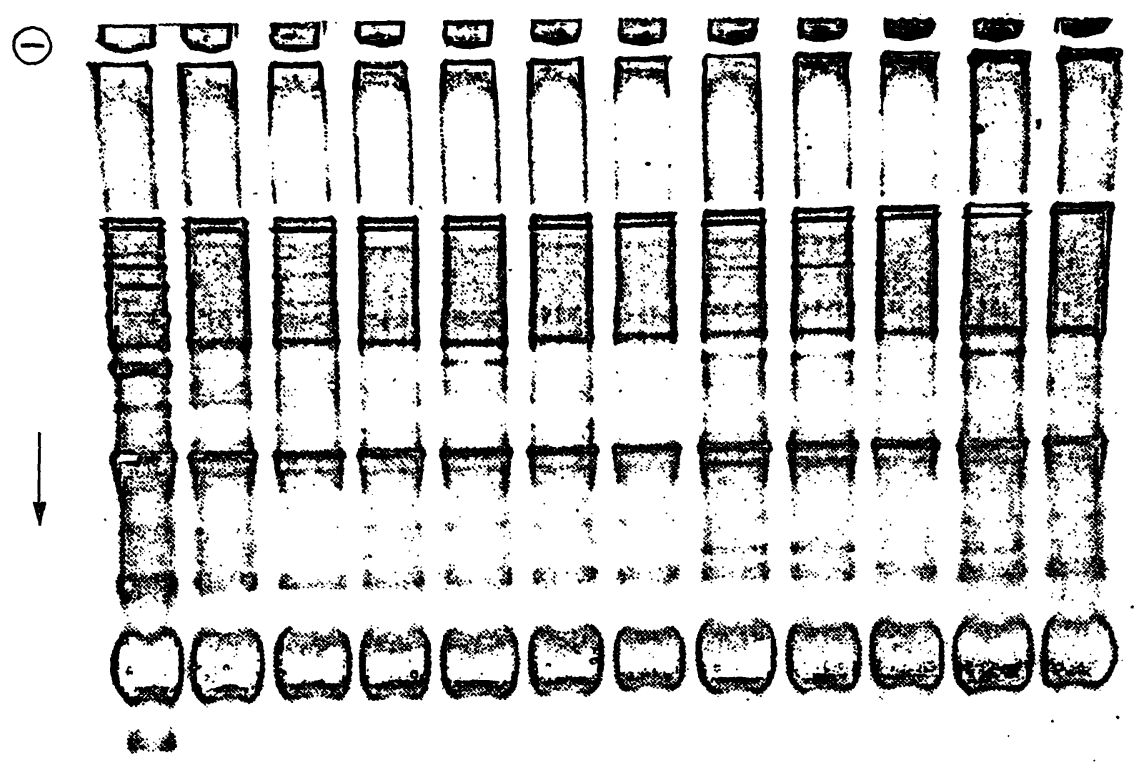

Fig. 1

Human serum proteins in standard ORNSTEIN-DAVIS gel system No. 1 (Tab. 1) in a flat slab gel ( $3 \mathrm{~mm}$ thick). Sample quantities: $200 \mu \mathrm{g}$ protein on each. Constant current of $60 \mathrm{~mA}$. Coomassie Blue $R 250$ staining

Fig. 2

Human serum proteins in ALLEN's gel system No. 1 (Tab. 2) in a flat slab gel ( $3 \mathrm{~mm}$ thick) using a $8-6-3.5 \%$ step concentration gradient. Other conditions see Figure 1

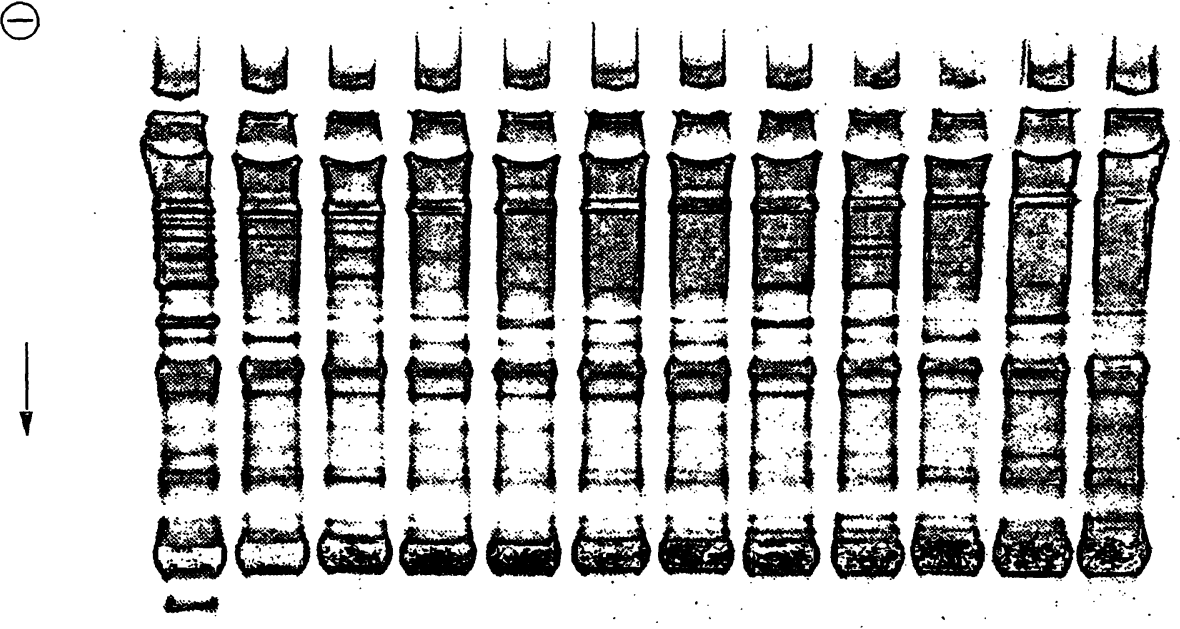

The improved separation obtained by ALLEN's system is mainly due to the step (discontinuous) polyacrylamide gradient which sharpens boundaries as they pass gel concentration discontinuities. Gradient gel electrophoresis considerably increases the versatility of polyacrylamide gel electrophoresis and deserves, therefore, particular attention if high resolution of distinct protein bands is desired. The method includes several parameters, and hence it offers a wide choice of conditions: Different acrylamide and/or cross-linker concentration gradients can be formulated; moreover, the form (linear, stepped, concave, convex) and the slope of the gradient may be modified. Methods for the preparation of gradient gels and problems related to these methods are described and discussed elsewhere (1).

It follows from theoretical considerations and practical observations that there hardly exists a single gel system which would be optimal for the resolution of all proteins of a complex biological fluid. It is rather advisable, in developing a particular gel system, to limit the goal in each case to optimum separation of the proteins of interest. Two equations developed by RODBARD and Chrambach $(2,22,23)$ may serve as guidelines for the optimization of separation and resolution. These require knowledge of the retardation coefficient and the free mobility to calculate the gel concentration for maximal separation and for optimal resolution. More- 


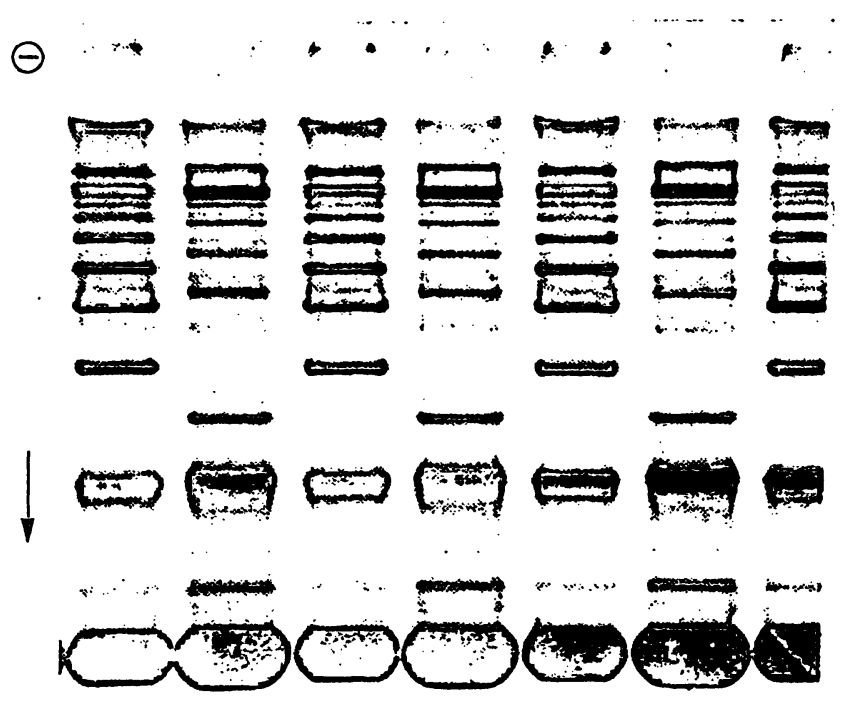

$\oplus$

Fig. 3

Human serum proteins in ALLEN's gel system No. 1 (Tab. 2) using half ionic strength, a $12-8-6-4.5 \%$ step concentration gradient and pulsed constant power $(280 \mathrm{~V}, 1.0 \mathrm{MFD}$, pulse rate increased from 75-300 PPS over first 20 min. in 3 steps of 75 pulses each at $5 \mathrm{~min}$. intervals). Alternating normal serum and myéloic leukemia serum proteins (from left to right) separated. Other conditions see

over, Jovin and coworkers $(3,4)$ developed a theory of multiphasic buffer systems and a computer program based on this theory permitting operation at any $\mathrm{pH}$, at $0^{\circ}$ or $25^{\circ}$, thus introducing a new dimension of versatility into fractionation. For example, electrophoresis at several $\mathrm{pH}$ values allows charge fractionation, the construction of $\mathrm{pH}$ activity and stability profiles as well as titration curves. The usefulness and applicability of these systems in clinical chemistry have still to be examined.

\section{Appendix \\ New Staining Procedures}

\section{Proteins with Coomassie Brilliant Blue $R 250$}

The proteins are first fixed by incubating the gel in $12.5 \%$ trichloroacetic acid at $65^{\circ}$ for $30 \mathrm{~min}$. The gel is rinsed with tap water and stained with a mixture of Coomassie Brilliant Blue R $250 \quad(0.2 \%$ water/absolute ethanol/glacial acetic acid, $45: 45: 10, V / V)$ at $65^{\circ}$ for $30 \mathrm{~min}$. The gel should be turned over aftcr $10 \mathrm{~min}$. in the stain. This procedure is also suited for isoclectric focused gels.

\section{Lipoproteins with Lipid Crimson}

$3 \mathrm{~g}$ of Lipid Crimson (see (1)) are dissolved in $600 \mathrm{ml}$ of $95 \%$ ethanol, $400 \mathrm{ml}$ water are added and the solution allowed to age one week. Following filtration, the gel is stained $2 \mathrm{hrs}$ at $65^{\circ}$ and left overnight at room temperature in the same stain. Destaining is performed with $10 \%$ acetic acid, with 3 to 4 changes in a $24 \mathrm{hr}$ period.

\section{$R N A$ with Stains-All (25)}

Formamide is adjusted to $\mathrm{pHI} 7.3-7.4$ with concentrated $\mathrm{HCl}$. $0.1 \%$ of the dye is dissolved and the stock solution stored protected from light at $4^{\circ}$. The working solution is freshly prepared by mixing 5 volume parts of stock solution, 45 parts of formamide (pH 7.3) and 50 parts of water. The gel is stained $1 \mathrm{hr}$ at room temperature in a dark place. Destaining is with water. The stain rapidly fades when exposed to strong light.

\section{References}

1. Maurer, H. R., Disc Electrophoresis and Related Techniques of Polyacrylamide Gel Electrophoresis, Walter de Gruyter, Berlin-New York, 224 pages, 2nd revised and expanded edition 1971. First edition: Disk-Elektrophorese, Theorie und Praxis der diskontinuierlichen Polyacrylamidgel-Elektrophorese, Walter de Gruyter, Berlin 1968. - 2. GordoN, A. H., in: Laboratory Techniques in Biochem. and Mol. Biol. Vol. 1, part 1, Work, T. S., and Work, E., editors, North-Holland Publ. Co. p. 1-145, Amsterdam-London (1969). - 3. Chrambach, A. and D. RodBARD, Science 172, 440 (1971). - 4. Jovin, T. M., M. L. DANTE and A. Chrambach, Multiphasic Buffer Systems Output (Nat. Techn. Inform. Serv. Springfield, Va., USA) PB 196085 to 196091 (1970). 5. MAURer, H. R. and R. C. AltëN, in preparation. - 6. ORNsterv, L., Annals N. Y. Acad. Sci. 121, 321 (1964). - 7. Davis, B. J., Annals N. Y. Acad. Sci. 121, 404 (1964). - 8. Canalco Chemical Formulations for Disc Electrophoresis (1965). 9. Williams, D. E. and R. A. Reisfeld, Annals N. Y. Acad. Sci. 121, 373 (1964). - 10. TABER, H. W. and F.'S Sherman, Annals
N. Y. Acad. Sci. 121, 600 (1964). - 11. Jolley, W. B. and H. W. Allen, Nature 208, 390 (1965). - 12. ReISFELd, R. A., U. J. Lewis and D. E. Wrlliams, Nature 195, 281 (1962). - 13. SHEPHERD, G. R. and L. R. GurLeY, Analytic. Biochem. 14, 356 (1966). - 14. ORTEC Instruction Manual Model 4200 Electrophoresis System (1969). - 15. ORTEC A 32 Techniques for High Resolution Electrophoresis (1970). - 16. ORTEC Instruction Manual Model 4217 Electrophoresis System (1971). 17. HJertén, S., S. Jerstedt and A. Tiselius, Analytic. Biochem. 11, 219 (1965). - 18. Poulik, M. D., Nature 180, 1477 (1957). 19. Brewer, J. M., Science 156, 256 (1967). - 20. King, E. E., J. Chromatog. 53, 559 (1970). - 21. LeRCH, B. and H. STEGEMANN, Analytic. Biochem. 29, 76 (1969). - 22. RodBARD, D. and A. Chrambach, Proc. Nat. Acad. Sci., USA 65, 970 (1970). 23. Rodbard, D., G. Kapadia and A. Chrambach; Analytic. Biochem. 40, 135 (1971). - 24. Rodbard, D. and A. Chrambach, Analytic. Biochem. 40, 95 (1971). - 25. Dahlberg, A. E., C. W. Dingman and A. C. Peacock, J. Mol. Biol. 41, 139 (1969).

Dr. Hans Rainer Maurer Max-Planck-Inst. f. Virusforschung 74 Tübingen/Germany Spemannstr. 35 